\title{
8. SOME AGES FROM LEG 104 SITE 642 OBTAINED BY RB-SR GLAUCONITE DATING AND SR ISOTOPE STRATIGRAPHY1
}

\author{
P. C. Smalley, ${ }^{2}$ G. Qvale, ${ }^{3}$ and H. Qvale ${ }^{2}$
}

\begin{abstract}
We have attempted to date several samples from Site 642 using a combination of $\mathrm{Sr}$ isotope stratigraphy and $\mathrm{Rb}-\mathrm{Sr}$ dating of glauconite. A carbonate shell fragment from Sample 104-642B-22H-6, 70-73 cm gives a Sr isotope stratigraphy date of $17.3 \pm 1.0 \mathrm{Ma}$, which agrees well with available biostratigraphic and paleomagnetic data. Glauconites from a nearby sample (104-642B-23H-1, 66-69 cm) give a similar date.

One carbonate shell fragment and two fish teeth samples from Core 104-642D-12X give concordant $\mathrm{Sr}$ isotope stratigraphy ages of about $37 \mathrm{Ma}$ (latest Eocene). Rb-Sr glauconite analyses from one of the samples, while showing some substrate contamination, also support an Eocene age. Our results are in conflict with Miocene palynomorph dates from Core 104-642D-12X. As specific reworking of fish teeth and carbonate macrofossils (and also glauconite) from $37 \mathrm{Ma}-$ old sediments into three different samples in Core 104-642D-12X is most unlikely, we view the 37-Ma date as the depositional age of the core.
\end{abstract}

\section{INTRODUCTION}

$\mathrm{Rb}-\mathrm{Sr}$ isotopic age analysis of glauconite in conjunction with Sr isotope stratigraphy is a powerful dating method if these two independent procedures yield internally consistent results. $\mathrm{Sr}$ isotope stratigraphy is based on the temporal variation of ${ }^{87} \mathrm{Sr} /$ ${ }^{86} \mathrm{Sr}$ in ocean water (Burke et al., 1982). A curve reflecting ${ }^{87} \mathrm{Sr} /$ ${ }^{86} \mathrm{Sr}$ variations in ancient seawater may be constructed using $\mathrm{Sr}$ isotope analyses of paleontologically well-dated carbonate or phosphate fossils of different ages (Fig. 1). By reference to this curve ${ }^{87} \mathrm{Sr} /{ }^{86} \mathrm{Sr}$ in a fossil of unknown age can be precisely assigned ( \pm 0.5 to $3.0 \mathrm{Ma}$ in the Cenozoic) to a corresponding depositional age. The method is not influenced by biofacies or faunal provincialism, and can be performed on very small samples $(0.1 \mathrm{mg})$. $\mathrm{Rb}-\mathrm{Sr}$ glauconite studies can give more precise depositional ages $( \pm<0.2 \mathrm{Ma}, 2 \sigma)$, but these age determinations are sometimes either anomalously old due to inheritance of $\mathrm{Sr}$ from detrital substrate material, or anomalously young due to diagenetic modification (e.g. Morton and Long, 1982; Smalley et al., 1986). Such problems should easily be recognized by discordant results from $\mathrm{Sr}$ isotope stratigraphy and $\mathrm{Rb}-\mathrm{Sr}$ dating of glauconite. For an apparent age to be accepted as a true depositional age the following criteria must be fulfilled:

1. Data for different glauconite fractions separated on the basis of color, size or morphology from a single sample and coexisting marine carbonate should fall on an isochron, indicating that glauconite was formed in $\mathrm{Sr}$ isotope equilibrium with seawater.

2. Data for the marine carbonate fraction should plot on the ${ }^{87} \mathrm{Sr} /{ }^{86} \mathrm{Sr}$ seawater curve at the date defined by the isochron.

This approach has previously yielded age information on samples from DSDP Site 341 on the Vøring Plateau (Smalley et al., 1986) and for Cenozoic rocks in the northern North Sea (Y. Rundberg and P. C. Smalley, unpubl. data). In the present study these same methods are applied to samples from ODP Site 642 .

${ }^{1}$ Eldholm, O., Thiede, J., Taylor, E., et al., 1989. Proc. ODP, Sci. Results, 104: College Station, TX (Ocean Drilling Program).

${ }^{2}$ Institute for Energy Technology, P.O. Box 40, N-2007 Kjeller, Norway.

3 Norsk Hydro, P.0. Box 200, N-1321 Stabekk, Norway.

\section{SAMPLES AND ANALYTICAL METHODS}

Five samples were selected for study (Fig. 2): Sample 104-642D-12X$2,78-81 \mathrm{~cm}$ [288.8 meters below sea floor (mbsf)] which contained abundant glauconite and phosphatic fish teeth; Samples 104-642D-12X4 , 81-84 cm (291.8 mbsf) and 104-642D-12X-5, 145-149 cm (294.0 mbsf) which contained, respectively, carbonate macrofossil (bivalve) fragments and phosphatic fish teeth; Sample 104-642B-23H-1, 66-69 $\mathrm{cm}$ (196.7 mbsf) which contained glauconite but lacked carbonate or phosphate, and Sample 104-642B-22H-6, 70-73 cm (194.9 mbsf) which was the nearest sample that contained carbonate.

Disaggregated samples were passed through a Frantz isodynamic separator to obtain glauconite, phosphate, and carbonate concentrates. Individual grains were then hand picked to give fractions with a visual purity of $100 \%$. Glauconite pellets were subdivided into different fractions based on color, correlating with crystallinity and K-content (Odin, 1982), and morphology.

Three fractions were separated from Sample 104-642D-12X-2, 78-81 $\mathrm{cm}$ : light green glauconite (lg), very light green glauconite (vlg), and fish teeth (ft). Three glauconite fractions were separated from Sample 104642B-23H-1, 66-69 cm: medium green $(\mathrm{mg})$, medium green spheres (mgs), and dark green (dg). Single fragments of carbonate macrofossil shell (s) were picked from Samples 104-642-22H-6, 70-73 cm and 104$642 \mathrm{D}-12 \mathrm{X}-4,81-84 \mathrm{~cm}$. Approximately 20 fish teeth were picked from Sample 104-642D-12X-5, 145-149 cm. None of the glauconite samples were clearly replacing granular detrital precursors, but the presence of a fine-grained detrital clay component could not be discounted. The rounded or lobate shapes could indicate replacement of fecal pellets or oncoids. The Sample 104-642B-23H-1, 66-69 cm mgs fraction constituted glauconites clearly replacing spherical siliceous tests, probably from radiolarians, although only grains showing complete replacement were selected. Judging by color, the glauconites ranged from littleevolved to evolved using the terminology of Odin and Matter (1981). None of the fractions were large enough to permit XRD study. The fish teeth appeared totally pristine, and careful optical examination of the carbonate shells revealed no evidence of new (diagenetic) carbonate growth. Neither the fish teeth nor the carbonate shells showed any sign of abrasion, or any other evidence of transport during sedimentation.

The individual glauconite fractions weighed 2 to $20 \mathrm{mg}$ and the carbonate/phosphate fractions weighed ca. $0.2 \mathrm{mg}$. Glauconite fractions were first cleaned of any adhering grains by ultrasonification, leached briefly in cold $0.1 \mathrm{~N} \mathrm{HCl}$ to ensure that no carbonate was present, and then leached for $24 \mathrm{hr}$ in $1 \mathrm{~N}$ ammonium acetate solution to remove exchangeable $\mathrm{Rb}$ and $\mathrm{Sr}$ ions (Morton and Long, 1982), followed by repeated washing in acetone and water. Fractions were then spiked with a mixed ${ }^{87} \mathrm{Rb}-{ }^{84} \mathrm{Sr}$ tracer and dissolved in a HF- $\mathrm{HNO}_{3}$ mixture. $\mathrm{Rb}$ and $\mathrm{Sr}$ were concentrated by standard ion exchange techniques using $1.5 \mathrm{ml}$ minicolumns ( $5 \mathrm{~mm}$ diameter) filled with BioRad AG50 $(\times 8,200-400$ mesh resin. 


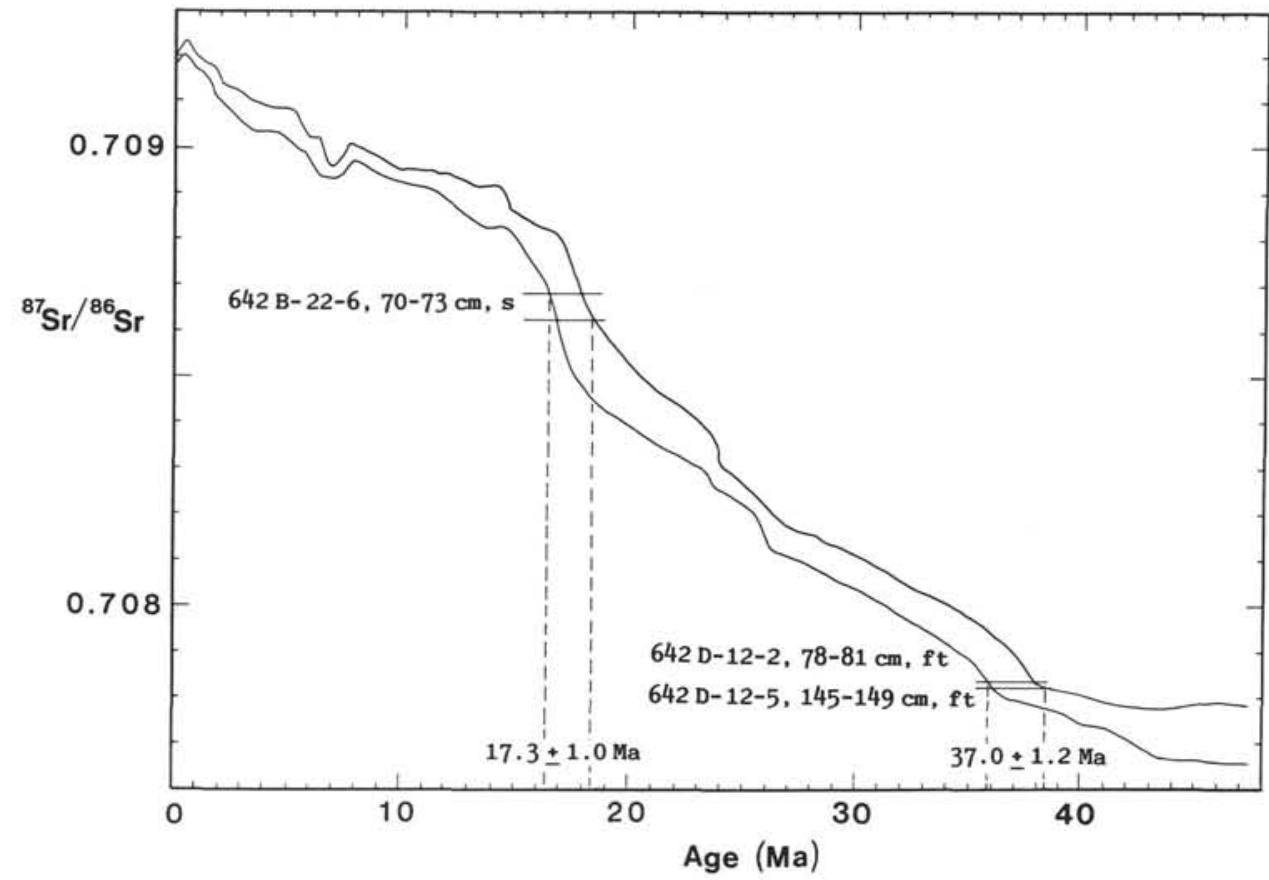

Figure $1 .{ }^{87} \mathrm{Sr} /{ }^{86} \mathrm{Sr}$ variations in seawater during Cenozoic time. Data sources and method of construction are described in the text. Derivation of dates for three of the analyzed samples from Site 642 is also illustrated $(\mathrm{s}=$ shell, $\mathrm{ft}=$ fish teeth).

104-642B

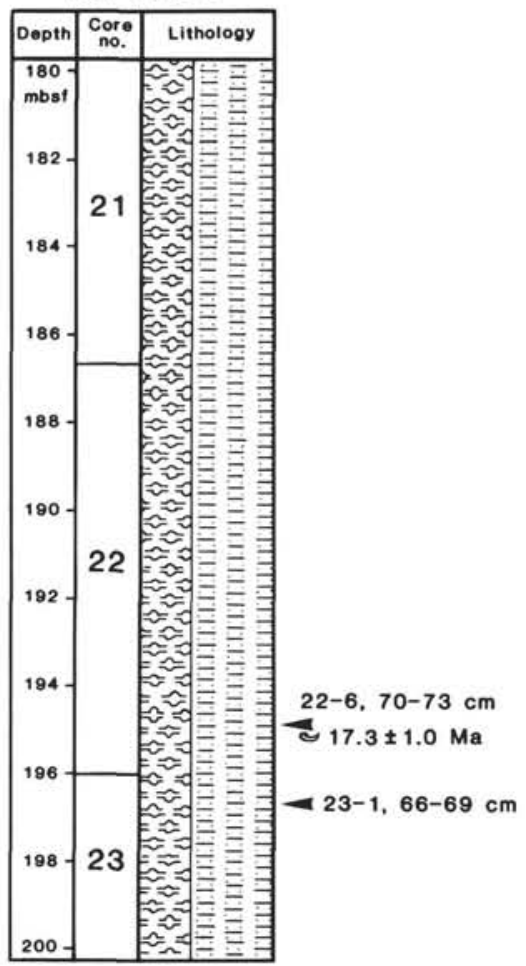

104-642D

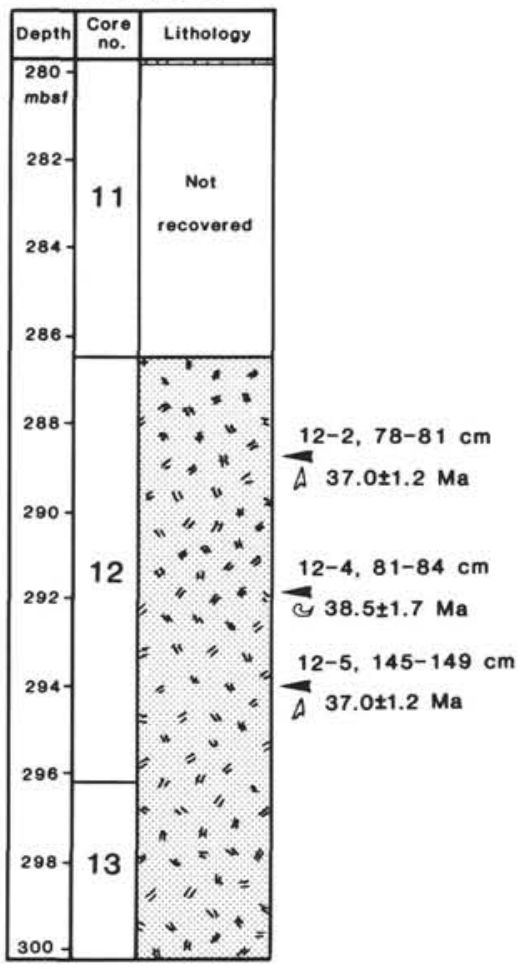

Figure 2. Simplified lithological section of Core 104-642B, 180-200 mbsf (siliceous mud) and Core 104-642D, 280-300 mbsf (glauconite-rich pyroclastic sand and sandy mud). The arrows indicate where the samples were taken. The ages were obtained by $\mathrm{Sr}$ isotope stratigraphy from bivalve fragments and fish teeth. Glauconites only were sampled from Section 104-642B-23H-1. 
The carbonate and phosphate fractions were cleaned ultrasonically and also, for the phosphate, by brief leaching in $0.1 \mathrm{~N} \mathrm{HCl}$, prior to dissolution in $1.5 \mathrm{~N} \mathrm{HCl}$ and subsequent ion exchange. Total chemical blanks, $<200 \mathrm{pg}$ for $\mathrm{Sr}$, were negligible. $\mathrm{Sr}$ isotope measurements were made on a Finnigan MAT 261 mass spectrometer in the static multicollector mode. Rb measurements were performed on a VG MM30 mass spectrometer at the Mineralogical-Geological Museum, University of Oslo. Measured ${ }^{87} \mathrm{Sr} /{ }^{86} \mathrm{Sr}$ was normalized to ${ }^{86} \mathrm{Sr} /{ }^{88} \mathrm{Sr}=0.1194$. The NBS 987 standard yielded $0.71025 \pm 0.00001(2 \sigma, n=11)$. Age calculations utilize the method of York (1969), using in-run ${ }^{87} \mathrm{Sr} /{ }^{86} \mathrm{Sr}$ precisions and an assigned precision of $1 \%(2 \sigma)$ for ${ }^{87} \mathrm{Rb} /{ }^{86} \mathrm{Sr}$. All uncertainties are quoted at the $2 \sigma$ level.

Our estimate of the seawater $\mathrm{Sr}$ isotope curve is based on a compilation of about 300 data points taken from Palmer and Elderfield (1985), Depaolo and Ingram (1985), DePaolo (1986), Hess et al. (1986), Koepnick et al. (1985), and our own unpublished results. For the Koepnick et al. data, only the DSDP samples described as having $<4 \%$ insoluble residue were included in the compilation. We used the time scale of Berggren et al. (1985). Values from each of the above-mentioned sources were normalized to a value of 0.70920 for Holocene marine carbonate to correct for interlaboratory bias. The individual data were enclosed by arbitrary limits (Fig. 1), excluding obvious outliers (ca. 10\% of the points). Ages in the present study were calculated by taking the $\pm 2 \sigma$ limits of uncertainty for each ${ }^{87} \mathrm{Sr} /{ }^{86} \mathrm{Sr}$ analysis and reading off the dates at the seawater curve (Fig. 1). The age of the sample is expressed as the median value with an associated uncertainty of plus or minus half the possible age range.

\section{RESULTS AND DISCUSSION}

The isotopic results (Table 1) are plotted in Figure 3.

By reference to the marine ${ }^{87} \mathrm{Sr} /{ }^{86} \mathrm{Sr}$ curve (Fig. 1) the fish teeth ( $\mathrm{ft}$ ) from Sample 104-642D-12X-2, 78-81 cm give a date of $37.0 \pm 1.2 \mathrm{Ma}$. Phosphatic remains such as fish teeth are known to be resistant to diagenetic modification of their ${ }^{87} \mathrm{Sr} /$ ${ }^{86} \mathrm{Sr}$ ratios (Shaw and Wasserburg, 1985; Staudigel et al., 1986), and if, as we have done, care has been taken in cleaning the teeth, they should preserve the ${ }^{87} \mathrm{Sr} /{ }^{86} \mathrm{Sr}$ of the seawater in which the fish lived. We thus believe this date to record the depositional age of the sample accurately. The two glauconite fractions from this sample do not fulfill the criteria for an ideal $\mathrm{Rb}-\mathrm{Sr}$ glauconite system recording a depositional age. A regression of the data for glauconite and fish teeth samples gives a poor correlation, with a high MSWD (mean square of weighted deviates) of 352 (in a true isochron this value should be $<2.5$ ), and a poorly defined apparent age of $42.7 \pm 5.8 \mathrm{Ma}$. Rb-Sr model ages for the individual glauconite fractions (Table 1) are 39.6 Ma for the light green fraction and $45.4 \mathrm{Ma}$ for the very light green fraction. Their light color suggests them to be littleevolved (Odin and Matter, 1981). Such glauconites are susceptible to inheritance of $\mathrm{Sr}$ from the glauconite precursor material. In the present case this may have included detrital clays, thus leading to anomalously old $\mathrm{Rb}-\mathrm{Sr}$ model ages. Even so, the model age of $39.6 \mathrm{Ma}$ for the light green fraction is close to that recorded by the fish teeth. Unfortunately, more highly evolved glauconites, which constitute more reliable material for dating (Odin, 1982), are not present in this sample, and are, in fact, rare throughout the sequence.

The carbonate (macrofossil) and fish teeth fractions from Samples 104-642D-12X-4, 81-84 cm and 104-642D-12X-5, 145$149 \mathrm{~cm}$ yielded dates of $38.5 \pm 1.7 \mathrm{Ma}$ and $37.0 \pm 1.2 \mathrm{Ma}$, respectively. These samples are situated $2.04 \mathrm{~m}$ and $5.18 \mathrm{~m}$, respectively, below Sample 104-642D-12X-2, 78-81 cm and give indistinguishable dates. The three $\mathrm{Sr}$ isotope stratigraphy ages of about $37 \mathrm{Ma}$ in Core 104-642D-12 are highly consistent. Both carbonate and phosphate material were analyzed, and thus it is unlikely that reworking of the mechanically resistant fish teeth or diagenetic alteration of carbonate has affected the samples.

${ }^{87} \mathrm{Sr} /{ }^{86} \mathrm{Sr}$ from the Sample $104-642 \mathrm{~B}-22 \mathrm{H}-6,70-73 \mathrm{~cm}$ carbonate shell fragment plots on the seawater curve at $17.3 \pm 1.0$

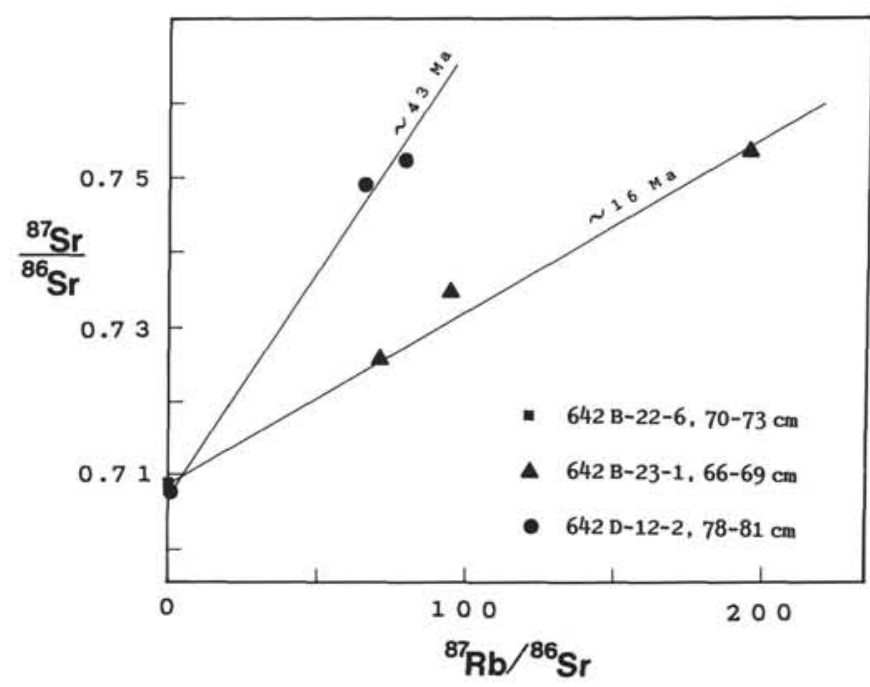

Figure 3. $\mathrm{Rb}$-Sr isochron diagram for samples from Site 642. For exact isochron parameters see text.

Ma (Fig. 1), which we interpret as the time of deposition. Data for the three glauconite fractions from Sample 104-642B-23H-1, $66-69 \mathrm{~cm}$ give a poorly correlated array on a $\mathrm{Rb}-\mathrm{Sr}$ isochron diagram (Fig. 3). The apparent age is $16.7 \pm 7.2 \mathrm{Ma}$, and the MSWD value (610) is high, denoting disequilibrium at the time of deposition. The carbonate shell fragment from the overlying sample could justifiably be included on the isochron calculations. The resulting four-point regression yields $17.3 \pm 1.8 \mathrm{Ma}$, again with a very high MSWD (312). The main component of scatter is caused by the data point for the green spheres fraction which lies above the $16.3 \pm 0.6 \mathrm{Ma}(\mathrm{MSWD}=31)$ isochron defined by the three other fractions. This fraction has a higher $\mathrm{Rb}-\mathrm{Sr}$ model age (19.0 Ma) than those of the medium green and dark green fractions (16.7 and $16.0 \mathrm{Ma})$, probably because of inherited radiogenic Sr. It is unlikely that inherited $\mathrm{Sr}$ came from the replaced siliceous tests, as these should themselves have been precipitated in $\mathrm{Sr}$ isotope equilibrium with seawater. Possibly, the tests had been infilled with detrital clays prior to glauconitization. Although the $16.3 \pm 0.6 \mathrm{Ma}$ isochron has a high MSWD value, indicating that the isochron incorporates real geological scatter due to precursor inheritance or postdepositional disturbance, the close similarity to the $\mathrm{Sr}$ isotope stratigraphy date of $17.3 \pm 1.0 \mathrm{Ma}$ supports the validity of the latter date.

Extensive biostratigraphic and paleomagnetic studies have been carried out on samples from Site 642 (e.g., Bleil; Donnally; Goll and Bjørklund; Spiegler and Jansen, all this volume). The results from these studies are in good agreement with the dates reported here for the 642B samples, while there are discrepancies with the palynological dating of the 642D cores. In Hole 642D (Core 11 and downwards) palynomorphs were the only fossils present in such abundances that they can be used as a stratigraphic tool. The palynological studies of $642 \mathrm{D}$ samples (Manum et al., this volume) have shown the presence of a hiatus between Sections 104-642D-13X-3 and 104-642D-13X-1. In Section 104-642D-13X-3 and downward an assemblage indicating an early Eocene age was observed, while samples from Section 104-642D-13X-1 and shallower contain an assemblage which could be interpreted as indicating an age no greater than early Miocene (Manum et al., this volume). Our date of $37.0 \pm 1.2$ Ma (latest Eocene) for Core 104-624D-12X thus contradicts the palynomorph age. This discrepancy could be explained by palynomorph contamination from the shallower part of the bore- 
Table 1. Analytical results of Leg 104 samples. See text for sample explanation and abbreviations.

\begin{tabular}{|c|c|c|c|c|c|c|c|}
\hline Sample & Material & $\mathrm{Rb}^{1}$ & $\mathrm{Sr}^{1}$ & $\mathrm{Rb} / \mathrm{Sr}$ & ${ }^{87} \mathrm{Rb} /{ }^{86} \mathrm{Sr}^{2}$ & ${ }^{87} \mathrm{Sr} /{ }^{86} \mathrm{Sr} \pm 2 \sigma$ & Date $(\mathrm{Ma})^{3}$ \\
\hline $104-642 \mathrm{~B}-23 \mathrm{H}-1,66-69 \mathrm{~cm}$ & mgs & 174.2 & 5.32 & 32.7 & 94.9 & $0.73432 \pm 0.00009$ & 19.0 \\
\hline 104-642B-23H-1, 66-69 cm & $\mathrm{mg}$ & 163.8 & 6.75 & 24.3 & 70.3 & $0.72531 \pm 0.00003$ & 16.7 \\
\hline $104-642 \mathrm{~B}-23 \mathrm{H}-1,66-69 \mathrm{~cm}$ & $\mathrm{dg}$ & 239.2 & 3.55 & 67.4 & 195.7 & $0.75318 \pm 0.00003$ & 16.0 \\
\hline $104-642 \mathrm{~B}-22 \mathrm{H}-6,70-73 \mathrm{~cm}$ & s & & & & & $0.708662 \pm 0.000025$ & $17.3 \pm 1.0$ \\
\hline 104-642D-12X-2, 78-81 cm & $\lg$ & 147.1 & 5.42 & 27.2 & 78.9 & $0.75226 \pm 0.00009$ & 39.6 \\
\hline $104-642 \mathrm{D}-12 \mathrm{X}-2,78-81 \mathrm{~cm}$ & vig & 116.2 & 5.19 & 22.4 & 65.1 & $0.74976 \pm 0.00003$ & 45.4 \\
\hline 104-642D-12X-2, 78-81 cm & $\mathrm{ft}$ & & & & & $0.707828 \pm 0.000006$ & $37.0 \pm 1.2$ \\
\hline 104-642D-12X-4, 81-84 cm & s & & & & & $0.707811 \pm 0.000012$ & $38.5 \pm 1.7$ \\
\hline $104-642 \mathrm{D}-12 \mathrm{X}-5,145-149 \mathrm{~cm}$ & $\mathrm{ft}$ & & & & & $0.707825 \pm 0.000006$ & $37.0 \pm 1.2$ \\
\hline
\end{tabular}

\footnotetext{
${ }^{1}$ Concentrations measured by isotope dilution.

${ }^{2}$ Precise to $\pm 1 \%(2 \sigma)$.

${ }^{3}$ Dates with quoted uncertainties obtained by marine $\mathrm{Sr}$ stratigraphy. Others are $\mathrm{Rb}-\mathrm{Sr}$ glauconite model dates using $\mathrm{I}(\mathrm{Sr})$ equivalent to ${ }^{87} \mathrm{Sr} /{ }^{86} \mathrm{Sr}$ of related carbonate/phosphate sample.
}

hole, or by the reworking of the fish teeth and macrofossil debris. It has been suggested that there may be some reworked sand in Core 104-642D-12X (Shipboard Scientific Party, 1987). The evidence for reworking is the presence of thin $(5-10 \mathrm{~cm})$ coarsening upward sand sequences separated by 20 - to $40-\mathrm{cm}$ thick beds of homogeneous mud in Sections 2, 5, and 6. The reworking hypothesis is favored by Manum et al. (this volume), but, while theoretically possible, we view this as highly unlikely. The two fish teeth Samples (104-642D-12X-2, 81-84 cm and $104-642 \mathrm{D}-12 \mathrm{X}-5,145-149 \mathrm{~cm})$ gave very precise $\mathrm{Sr}$ isotope results with identical values $(0.707828 \pm 6,0.707825 \pm 6)$. Each sample consisted of about 20 individual teeth. If the samples had been reworked, but if just one fish tooth from one sample was in situ (i.e., early Miocene, ca. $22 \mathrm{Ma},{ }^{87} \mathrm{Sr} /{ }^{86} \mathrm{Sr}=$ ca. 0.70850 , see Fig. 1) then the ${ }^{87} \mathrm{Sr} /{ }^{86} \mathrm{Sr}$ of the 20 fish teeth would have been raised by about 0.00006 , which is an order of magnitude greater than the analytical precision. The only way to get such consistant results would be for every single fish tooth analyzed in both samples to be derived from $37.0 \pm 1.2 \mathrm{Ma}$-old sediments. Furthermore, the carbonate macrofossil debris, which would have very different hydrodynamic properties during deposition, would have to have been reworked in an exactly similar manner. Additionally, the glauconite fractions from Sample 104-642D-12X-2, 78-81 cm, while clearly displaying effects of inherited substrate $\mathrm{Sr}$, give Eocene model ages (Table 1). The model age for the most evolved glauconite fraction in the sample (lg) is $39.6 \mathrm{Ma}$, very close to the ca. $37 \mathrm{Ma}$ ages obtained by $\mathrm{Sr}$ isotope stratigraphy. It would thus appear that, for the reworking hypothesis to be correct, carbonates, macrofossils, and glauconite pellets would all have to have been affected in exactly the same way, which is not likely. If such had been the case one may wonder why the dinoflagellate cyst assemblages are not also reworked. To conclude, the close agreement of our results from Core 104-642D-12X makes the reworking hypothesis unlikely. Certainly, further dating using both biostratigraphic and isotopic methods would help to shed light on this problem.

The next nearest biostratigraphic date is from Section 104$642 \mathrm{D}-8 \mathrm{X}-5$. The silicoflagellates in a sample from this core indicate an age of 22.6-23.4 Ma (Ciesielski et al., this volume). $\mathrm{Pa}-$ leomagnetic measurements were carried out down to Section 104-642D-11X-1, which gave an age of $21.71 \mathrm{Ma}$ (Bleil, this volume). There is, however, evidence of a major hiatus in Section 104-642D-11X-1 at $94 \mathrm{~cm}$ where a sandy, glauconite and phosphate-rich hardground is observed. We believe this to represent very slow sedimentation or a hiatus and it also marks the shift in lithology from siliceous mud to glauconite-rich, pyroclastic sand (Shipboard Scientific Party, 1987). We suggest that this hiatus marks the boundary between upper Eocene sediments (Core 104-642D-12X) and the lower Miocene sediments found above.

\section{SUMMARY}

Four dates were obtained using $\mathrm{Sr}$ isotope stratigraphy. From Core 104-642D-12X the following dates were revealed: fish teeth in Sample 2, 78-81 cm, $37.0 \pm 1.2 \mathrm{Ma}$; a bivalve fragment in Sample 4, 81-84 cm, $38.5 \pm 1.7 \mathrm{Ma}$; fish teeth from Sample 5, $145-149 \mathrm{~cm}, 37.0 \pm 1.2 \mathrm{Ma}$. These data contradict the dates based on palynomorph assemblages, giving a late Eocene age as opposed to the early Miocene date obtained from the palynomorphs.

A carbonate shell fragment from Sample 104-642B-22H-6, $70-73 \mathrm{~cm}$ gave $17.3 \pm 1.0 \mathrm{Ma}$. This is in good agreement with the results from the biostratigraphic and paleomagnetic studies. $\mathrm{Rb}-\mathrm{Sr}$ glauconite isochrons from two samples support these marine $\mathrm{Sr}$ dates, but they display scatter exceeding that which can be attributed to experimental error. The main cause of this is probably inheritance of $\mathrm{Sr}$ from detrital glauconite precursor phases.

\section{ACKNOWLEDGMENTS}

Analytical facilities were provided by the Institute for Energy Technology and the Mineralogical-Geological Museum University of Oslo. B. M. Popp and L. E. Long, University of Oslo, are thanked for their constructive reviews.

\section{REFERENCES}

Berggren, W. A., Kent, D. V., Flynn, J. J., and van Couvering, J. A., 1985. Cenozoic geochronology. Bull. Geol. Soc. Am., 96:14071418.

Burke, W. H., Denison, R. E., Hetherington, E. A., Koepnick, R. B., Nelson, H. F., and Otto, J. B., 1982. Variation of seawater ${ }^{87} \mathrm{Sr} /{ }^{86} \mathrm{Sr}$ throughout Phanerozoic time. Geology, 10:516-519.

DePaolo, D. J., 1986. Detailed record of the Neogene Sr isotopic evolution of seawater from DSDP Site 590B. Geology, 14:103-106.

DePaolo, D. J., and Ingram, B. L., 1985. High-resolution stratigraphy with strontium isotopes. Science, 227:938-941.

Hess, J., Bender, M. L., and Schilling, J.-G., 1986. Evolution of the ratio of strontium- 87 to strontium-86 in seawater from the Cretaceous to present. Science, 231:979-984.

Koepnick, R. B., Burke, W. H., Denison, R. E., Hetherington, E. A., Nelson, H. F., Otto, J. B., and Waite, L. E., 1985. Construction of the seawater ${ }^{87} \mathrm{Sr} /{ }^{86} \mathrm{Sr}$ curve for the Cenozoic and Cretaceous: supporting data. Chemical Geology (Isotope Geoscience), 58:55-81.

Morton, J. P., and Long, L. E., 1982. Rb-Sr ages of glauconite crystallization: dating times of regional emergence above sea level. J. Sediment. Petrol., 54:495-506.

Odin, G. S., 1982. How to measure glaucony ages, In Odin, G. S. (Ed.), Numerical Dating in Stratigraphy: Chichester (Wiley), 387-403.

Odin, G. S., and Matter, A., 1981. De glauconiarum origine. Sedimentology, 28:611-641.

Palmer, M. R., and Elderfield, H., 1985. Sr isotopic composition of seawater over the past 75 Myr. Nature, 314:526-528. 
Shaw, H. F., and Wasserburg, G. J., 1985. Sm-Nd in marine carbonates and phosphates: Implications for $\mathrm{Nd}$ isotopes in seawater and crustal ages. Geochim. Cosmochim. Acta, 49:503-518.

Shipboard Scientific Party, 1987. Site 642: Norwegian Sea. In Eldholm, O., Thiede, J., Taylor, E., et al., Proc. ODP, Init. Repts., 104: College Station, TX (Ocean Drilling Program), 53-453.

Smalley, P. C., Nordaa, A., and Råheim, A., 1986. Geochronology and paleothermometry of Neogene sediments from the Vøring Plateau using Sr, C and O isotopes. Earth Planet. Sci. Lett., 78:368-378.
Staudigel, H., Doyle, P., and Zindler, A., 1986. Sr and Nd isotope systematics in fish teeth. Earth Planet. Sci. Lett., 76:45-56.

York, D., 1969. Least-squares fitting of a straight line with correlated errors. Earth Planet. Sci. Lett., 5:320-324.

Date of initial receipt: 7 August 1987

Date of acceptance: 16 March 1988

Ms 104B-178 